\title{
Relationship of Thyroid Hormone Status and Serum Fluoride Level among the Tribal Peoples - A Cross-sectional Descriptive Study
}

\author{
Authors \\ Suman Chatterjee ${ }^{1 *}$, Sumanta Banerjee ${ }^{2}$, Tanmay Ray ${ }^{3}$, Sailen Kumar Bhattacharyya ${ }^{4}$, \\ ${ }^{1,2}$ PGT, Department of Biochemistry, B.S.Medical College, Bankura \\ ${ }^{2}$ Email: drsumantab@gmail.com \\ ${ }^{3}$ PGT, Department of Microbiology, B.S.Medical College, Bankura \\ Email:dr.tanmayray@gmail.com \\ ${ }^{4}$ PGT, Department of Anatomy, B.S.Medical College, Bankura \\ Email:drsailenb@gmail.com \\ *Corresponding Author \\ Suman Chatterjee \\ PGT, Department of Biochemistry, B.S.Medical College, Bankura \\ Email: dr.sumanc2010@gmail.com
}

\begin{abstract}
Now-a-days, fluorosis is one of the important public health problems in many regions of Indian subcontinent. The present cross-sectional observational study had been undertaken at Simlapal block, one of the fluoride endemic zones of Bankura district, West Bengal, India to evaluate the relationship between thyroid hormone status and serum fluoride level among the tribal population. This study was carried on 67 fluorosis cases. Serum samples were collected from the cases and serum fluoride level was estimated by Ion-Meter and serum Thyroid stimulating hormone (TSH), free Triiodothyronine (fT3) and free Thyroxine (fT4) levels were measured by ELISA method. It was observed that there was a female preponderance in hypothyroidism compared to the male subjects who were suffering from fluorosis. This study also exposed that out of 67 cases 12 (ie, $17.91 \%$ ) were suffering from hypothyroidism.
\end{abstract}

Keywords- Fluorosis, Serum fluoride, TSH, fT3, fT4.

\section{Introduction}

The principal sources of fluorine are drinking water and food-stuff, such as sea fish, cheese and tea ${ }^{1}$. World Health Organization (WHO) has fix the upper limit of fluoride concentration in drinking water up to $1.0 \mathrm{mg} / \mathrm{L}^{2,3}$ and The Bureau of Indian Standard [BIS] has laid down the Indian standards as $1.5 \mathrm{mg} / \mathrm{L}$ as the maximum permissible limit of fluoride in drinking water with a further remark that "lesser the better"3. Therefore, WHO and BIS: 10500-1991 permit only up to $1.5 \mathrm{mg} / \mathrm{L}$ as safe limit of fluoride in drinking water for human consumption $^{1,2}$. Fluorosis is an important public health problem in 24 countries in the world, including India lying in the geographical fluoride belt that extends from Turkey to China and Japan through Iraq, Iran and Afghanistan ${ }^{4}$. Endemic fluorosis resulting from high fluoride concentration in groundwater is a major public health problem in India ${ }^{5}$ as large number of Indians depends primarily on groundwater for drinking purpose and day to day activities. Fluorine is often called as double-edged 
sword as prolonged ingestion of fluoride through drinking water in excess of the daily requirement is associated with dental, skeletal and non-skeletal fluorosis, whereas inadequate intake of fluoride in drinking water is associated with dental caries too ${ }^{2}$. In Bankura district of West Bengal, out of 22 blocks 17 are fluoride endemic areas, with high incidence of dental and skeletal and non-skeletal fluorosis symptomatic cases ${ }^{6}$. The thyroid gland produces two related hormones, thyroxine (T4) and triiodothyronine (T3). Through the thyroid hormone receptors namely, $\alpha$ and $\beta$, these hormones play a critical role in cell differentiation during development by regulating gene expression ${ }^{8}$ and help to maintain thermogenic and metabolic homeostasis in body ${ }^{7}$. Thyroid hormones are the fundamentals for development, growth, reproduction and metabolism. Many agents can alter the physiological functions of thyroid and its regulation. Fluoride is one of the known cause that influences all levels of function of thyroid gland, namely hormone production and secretion, hormonal actions etc. ${ }^{9,} 10$. The normal range of serum TSH, fT4 and fT3 are 0.4-4.2 mIU/L, 0.8-2.7 $\mathrm{ng} / \mathrm{dL}$ and 2.1-4.4 pg/mL, respectively ${ }^{11}$ and normal upper limit for fluoride in serum is $0.02 \mathrm{mg} / \mathrm{L}^{12}$. The tribal population in India is approximately $8.5 \%$ of the total population ${ }^{13}$ and Bankura has a quite large tribal population with few data of the impact fluorosis specially on them. In this background, this study had been conducted with an aim to evaluate the effects of fluorosis on the thyroid hormone profile among the tribal community.

\section{Materials and Methods \\ Study Area}

This cross-sectional descriptive study was conducted at Simlapal block of Bankura district in West Bengal, India. The biochemical analysis of samples was performed in the department of Biochemistry, Bankura Sammilani Medical College and Hospital, Bankura (at District fluorosis Detection Laboratory).

\section{Sample Size}

Total 203 samples

\section{Study Duration}

September, 2015 to March, 2016.

\section{Study Subject}

We included 203 tribal people from the study block by simple random sampling. They were physically examined and the informations pertaining to demographics, nature of illness were collected from them using a predesigned and pretested questionnaire. Informed consents were also taken from them. The study design was approved by the institutional ethical committee.

\section{Inclusion Criteria}

1. All male and female persons who were aged between 5 years to 70 years and not suffering from any acute illness.

2. Serum fluoride level was measured and persons with serum fluoride level $>0.02$ $\mathrm{mg} / \mathrm{L}$ were assigned to study group and those with serum fluoride level $\leq 0.02 \mathrm{mg} / \mathrm{L}$ were assigned to control group.

\section{Exclusion Criteria}

1. Persons suffering from any documented endocrine disorders

2. Subjects taking drugs for thyroid dysfunction (hypothyroid or hyperthyroid)

3. Persons having history of acute/ chronic illness, Pregnancy.

4. Patients taking drugs (eg. Lithium or Steroid) which can interfere with thyroid function tests.

\section{Method of Sample Collection}

$5 \mathrm{~mL}$ of fasting venous blood samples were collected in plain vials and allowed to clot in a tilted position until the straw colored clear serum was visible at the top of the clot in the vials. The vials were centrifuged at $3000 \mathrm{rpm}$ for 10 minutes. The serum samples were pipetted out from the vials and stored in separate, appropriately labeled aliquots at $-20^{\circ} \mathrm{C}$, until analysis was done.

\section{Parameters under Study}

i. Thyroid function tests - Serum TSH, fT4 and fT3 done by Enzyme Linked Immune Sorbent Assay (ELISA) method. 
ii. Serum fluoride - Serum fluoride levels were estimated by the Potentiometric method using "Ion sensitive electrode".

\section{Statistical Analysis}

The data were compiled in Microsoft excel sheet and analyzed by statistical methods as per need. Data were codified and displayed by charts and tables. Data were described by proportion, mean, standard deviation, range etc. Statistical tests like independent' $t$ ' test with $95 \%$ confidence interval (CI), Spearman correlation coefficient (r) etc. were used to evaluate the relationship between variables. $\mathrm{P}$ value of $<0.05$ was considered significant to discard the null hypothesis at 5\% precision and $95 \%$ confidence interval.

\section{Results}

Out of 203 participants 116 were male and rest were female.(Fig.1).

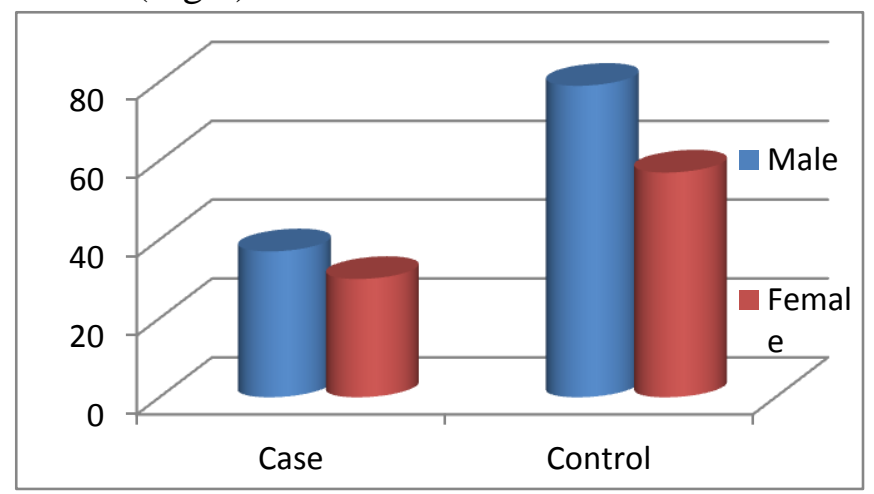

Figure-1: Distribution of Study Subjects according to Gender

The average age of the participants was $38.42 \pm 5.83$ (mean $\pm \mathrm{SD}$ ) years with a range of 65 years. The cases were found to have higher average serum TSH, fT4 and Fluoride levels compared to that of the controls and but the controls have higher serum fT3 level the difference was statistically robust (Table no-1).
Table-1: Age and serum levels of TSH, fT4, fT3 and Fluoride in Cases and control

\begin{tabular}{|l|l|l|l|l|l|}
\hline $\begin{array}{l}\text { S1 } \\
\text { No. }\end{array}$ & Parameters & $\begin{array}{l}\text { Control } \\
(\mathrm{n}=136) \\
\text { Mean } \pm \text { SD }\end{array}$ & $\begin{array}{l}\text { Case } \\
(\mathrm{n}=67) \\
\text { Mean } \pm \text { SD }\end{array}$ & $\begin{array}{l}P \\
\text { Value }\end{array}$ & Significance \\
\hline 1 & Age in years & $\begin{array}{l}37.49 \pm 13.2 \\
1\end{array}$ & $\begin{array}{l}35.73 \pm 11.9 \\
8\end{array}$ & 0.624 & Insignificant \\
\hline 2 & $\begin{array}{l}\text { TSH( } \\
\text { mIU/L) }\end{array}$ & $2.73 \pm 1.37$ & $9.15 \pm 2.92$ & 0.000 & $\begin{array}{l}\text { Highly } \\
\text { Significant }\end{array}$ \\
\hline 3 & fT4 (ng/dL) & $1.49 \pm 1.58$ & $1.57 \pm 0.76$ & 0.550 & Insignificant \\
\hline 4 & fT3 (pg/mL) & $2.54 \pm 0.55$ & $1.27 \pm 2.41$ & 0.656 & Insignificant \\
\hline 5 & $\begin{array}{l}\text { Fluoride } \\
\text { (mg/L) }\end{array}$ & $\begin{array}{l}0.01442 \pm 0 . \\
0019\end{array}$ & $\begin{array}{l}0.03664 \pm 0 . \\
0164\end{array}$ & 0.000 & $\begin{array}{l}\text { Highly } \\
\text { Significant }\end{array}$ \\
\hline
\end{tabular}

Table no-2 showed the Sex wise distribution of hypothyroidism in total study populations i.e. 29 (14.29\%) out of 203

Table-2: Sex wise Distribution of Hypothyroidism in total study Population

\begin{tabular}{|c|c|c|c|c|}
\hline & & \multicolumn{2}{|c|}{ Hypothyroidism } & \multirow{2}{*}{ Total } \\
\hline & & Absent & Present & \\
\hline \multirow[t]{2}{*}{ Sex } & Male & $105(90.52 \%)$ & $11(9.48 \%)$ & $\begin{array}{l}116 \\
(100 \%)\end{array}$ \\
\hline & Female & $69(79.31 \%)$ & $18(20.69 \%)$ & $87(100 \%)$ \\
\hline \multicolumn{2}{|c|}{ Total } & $174(85.71 \%)$ & $29(14.29 \%)$ & $\begin{array}{l}203 \\
(100 \%)\end{array}$ \\
\hline
\end{tabular}

Table no-3 showed the Sex wise distribution of hypothyroidism in case populations i.e. $12(17.91 \%)$ out of 67 cases

Table-3: Sex Distribution of Hypothyroidism in case population

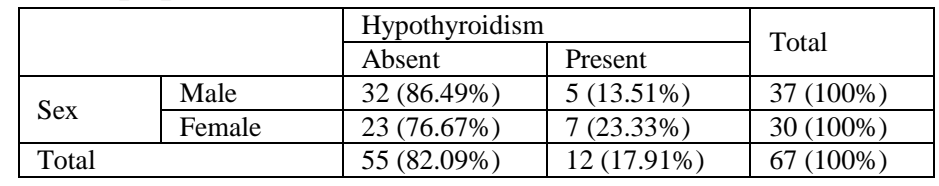

The serum fluoride was found to have a statistically significant negative linear relationship with TSH among the cases (Table-4).

Table-4: Relationship between the serum parameters among cases

\begin{tabular}{|l|l|l|l|}
\hline Parameter & Group & $\begin{array}{l}\text { Correlation } \\
\text { Co-efficient } \\
(\mathrm{r})\end{array}$ & $\begin{array}{l}\text { Significance } \\
\text { (p value) }\end{array}$ \\
\hline $\begin{array}{l}\text { Serum fluoride Vs } \\
\text { TSH }\end{array}$ & Case & $-0.542^{* *}$ & 0.001 \\
\hline $\begin{array}{l}\text { Serum fluoride Vs } \\
\text { fT4 }\end{array}$ & Case & 0.245 & 0.145 \\
\hline $\begin{array}{l}\text { Serum fluoride Vs } \\
\text { fT3 }\end{array}$ & Case & -0.319 & 0.054 \\
\hline Serum TSH Vs fT4 & Case & -0.226 & 0.179 \\
\hline Serum TSH Vs fT3 & Case & 0.043 & 0.799 \\
\hline SerumfT4 Vs fT3 & Case & 0.127 & 0.453 \\
\hline
\end{tabular}




\section{Discussion}

The fluoride, the negative ion of the element fluorine $\left(\mathrm{F}^{-}\right)$easily displaces the iodine in the body because it is much lighter and therefore more reactive and the activity of any one of the halogens is inversely proportion to its atomic weight. In other words, one halogen can displace another one of a higher atomic weight but cannot displace one of lower weight thereby results fluoride- thyroid-iodine antagonism which in turn lead to interference with iodine uptake ${ }^{14}$. In this present study out of 203 study subjects, males were $116(57.14 \%)$ and females were 87 (42.86\%).

In the present study it was observed that, there was a female preponderance in hypothyroidism compared to the male subjects; male, $\mathrm{n}=11(9.48 \%$ of total male population) and female $\mathrm{n}=18$ (20.69\% of total female populations). Ratio of male: female is 1: 1.64, which was almost corresponded with the findings of Gopalkrishnan Unnikrishnan A et al. ${ }^{15}$. In their study on prevalence of hypothyroidism in urban adults, was male: female ratio is 1: 2 . A study done by Yadav et al. ${ }^{16}$ reported male: female ratio of 1: 3 in the prevalence of hypothyroidism in Nepalese population.

In this study, out of 67 cases, it was found that 12 of them $(17.91 \%)$ were suffering from hypothyroidism i.e., having elevated serum $\mathrm{TSH}$, decreased serum fT3 and serum fT4. Similar findings were seen in the studies by Singla $S$ et al. in $2013^{17}$, where it was shown that increased fluoride levels decreased serum fT3, serum fT4 and an increased serum TSH levels.

A study done by Shashi A et al. ${ }^{9}$ on thyroid hormones in patients of fluorosis reported that all fluorosis cases had low T3, low T4, and increased TSH. They had suggested a significant depressed activity of the deiodinase enzymes due to fluoride accumulation in the soft tissues.

\section{Conclusions}

Bankura district of West Bengal is one of the most affected areas with fluorosis, where 17 out of 22 blocks are fluorosis endemic zones. Studies on the basis of the effects of fluorides on thyroid gland are not adequate and many study reports are contradictory. This present study showed that fluorosis can affect thyroid gland resulting hypothyroidism and it disclosed a significant correlation between the thyroid hormone level and serum fluoride concentration which enhances the fact of a clear relationship in between them but more extensive studies are required for estimating burden of the problem of hypothyroidism in presence of fluorosis.

\section{References}

1. Passmore R et al. Hand book of Human Nutritional Requirements. Monger Ser World Health Organ.1974; 61: 1-66.

2. Park K. Park's text book of Preventive and Social Medicine. $21^{\text {st }}$ Ed. Jabalpur, India: M/s Banarasisdas Bhanot Publishers. 2011: 577.

3. Guidelines for drinking water quality. Geneva: WHO; 2004.World Health Organization.

4. Saravanan $S$ et al. Prevalence of dental fluorosis among the primary school children in rural area of Chidambaram Taluk, Cuddalore District, Tamil Nadu. India, Indian J Commun Med.2008; 33: 146-50.

5. Kotecha PV, Patel SV, Bhalani KD, Shah D, Shah VS, Mehta KG. Prevalence of dental fluorosis \& dental carries in association with high levels of drinking water fluoride content in a district of Gujrat, Indian J Med Res. 2012; 135(6): 873-877.

6. National Programme For Prevention And Control of Fluorosis Bankura - Inter departmental Sensitization on Fluorosis. CMOH Office, Bankura. 2015.

7. Kasper D L, Fauci A S, Hauser S L, Longo D L, Jameson J L, Loscalzo J eds. Harrison's Principles of Internal Medicine. $19^{\text {th }}$ ed. USA: McGraw-Hill Education; 2015.

8. Murray RK. Harper's Illustrated Biochemistry. $29^{\text {th }}$ ed. McGrawHill Lange. 2012. 
9. Shasi A ,et al 2013. Clinical and Biochemical Profile of Deiodinase Enzymes and Thyroid Function Hormones in Patients of Fluorosis . Australian Journal of Basic and Applied Sciences. 2013; 7(4): 100-7.

10. Susheela A.K. Fluorosis management programme in India. Current Science. 1999; 77(10): 1250-1255.

11. Burtis CA, Ashwood ER, Bruns DE. Teitz textbook of Clinical Chemistry and Molecular Diagnostics. $5^{\text {th }}$ ed. USA: Elsevier Saunders; 2012.

12. Susheela AK, Bhatnagar M, Vig K, Mondal NK. Excess fluoride ingestion and thyroid hormone derangements in children living in Delhi, India. Fluoride. 2005; 38: 98-108.

13. Census of India 2011, Office of the Registrar General and Census Commissioner. Ministry of Home Affairs, Govt. of India. Available from: http:// www.censusindia.gov.in.

14. N. Singh et al. A comparative study of fluoride ingestion levels, Serum thyroid hormones and TSH level derangements, dental fluorosis status amongst school children from endemic and non-endemic fluorosis areas. Springerplus. 2014.

15. Gopalkrishnan AU et al. Prevalence of hypothyroidism in adults: An epidemiological study in eight cities of India. Indian Journal of Endocrinology and Metabolism. 2013; 17(4): 647-652.

16. Mahato RV, Nepal AK, Gelal B, Poudel B, Yadav BK, Lamsal M. Spectrum of thyroid dysfunction in patients visiting Kantipur Hospital, Kathmandu, Nepal. Mymensingh Med J. 2013; 22: 1649.

17. S. Singla et al. Thyroid peroxidase activity as toxicity target for fluoride in patients with thyroid dysfunction. Current Research in microbiology and Biotechnology. 2013; 2: 53-57. 